\title{
OPTIMALISASI KESADARAN HUKUM MASYARAKAT TERHADAP KEPASTIAN HUKUM SERTIFIKAT HAK ATAS TANAH
}

\author{
Rendy Renaldy ${ }^{1}$, Lina Maulidiana ${ }^{2}$ \\ Fakultas Hukum Universitas Sang Bumi Ruwai \\ rendy.fh.saburai@gmail.com, maulidianalina17@gmail.com
}

\begin{abstract}
Abstrak
Desa Sabah Balau merupakan kawasan dengan banyaknya lapangan kerja bagi petani untuk menggarap tanah yang secara regulasi dikuasai oleh PTPN VII, potensi masalah yang akan timbul mendatang seperti tumpang tindih pengakuan kepemilikan hak atas tanah, biasanya problem ini timbul ketika pamanfaatan lahan yang dikuasai oleh PTPN VII telah kadaluarsa, maka tanah tersebut akan dilepaskan kepada Negara serta Masyarakat Desa Sabah Balau punya hak perogratif untuk menguasai tanah bekas garapan tersebut baik seacara fisik maupun yuridis dengan ketentuan ganti rugi yang telah disepakati. Realita kasus tersebut akan menjadi penting untuk meningkatkan kesadaran hukum masyarakat Desa Sabah Balau mengenai arti pentingnya bukti kepemilikan hak atas tanah yang dalam hal ini adalah Sertifikat. Hasil pengabdian ini menjawab bahwa optimalisasi kesadaran hukum masyarakat Desa Sabah Balau terhadap kepastian hukum sertifikat hak atas tanah adalah dapat diaplikasikan dengan mendorong kemauan masyarkat Desa Sabah Balau untuk mendaftarkan tanahnya serta menanamkan rasa waspada akan terjadinya klaim sepihak dari pihak lain yang tidak bertanggungjawab yang berpotensi sengketa dikemudian hari, sedangkan kendala optimalisasi kesadaran hukum masyarakat Desa Sabah Balau terhadap kepastian hukum sertifikat hak atas tanah adalah belum adanya tindakan seperti pendampingan khusus terhadap sertifikasi tanah masyarakat Desa Sabah balau dan belum eksisnya edukasi dari stakeholder terkait seperti perangkat Desa, Pemerintah dan Akademisi baik secara formal maupun non formal.
\end{abstract}

Kata Kunci: Kesadaran Hukum, Kepastian Hukum, Sertifikat Hak Atas Tanah.

\begin{abstract}
Sabah Balau Village is an area with many jobs for farmers to work on land which is regulated by PTPN VII, potential problems that will arise in the future such as overlapping recognition of ownership of land rights, usually this problem arises when the use of land controlled by PTPN VII has expired, then the land will be released to the State and the people of Sabah Balau Village have the perogrative right to control the ex-cultivated land both physically and juridically with the agreed compensation provisions. The reality of this case will be important to increase the legal awareness of the people of Sabah Balau Village regarding the importance of proof of ownership of land rights, in this case a certificate.The results of this service answered that the optimization of the legal awareness of the people of Sabah Balau Village on the legal certainty of land rights certificates can be applied by encouraging the will of the Sabah Balau Village community to register their land and instilling a sense of alertness to the occurrence of unilateral claims from other irresponsible parties that have potential disputes in the future. days, while the obstacle to optimizing the legal awareness of the Sabah Balau Village community towards legal certainty of land rights certificates is the absence of action such as special assistance for land certification for the Sabah Balau Village community and there is no education from related stakeholders such as Village officials, the Government and Academics either formally or non-formal.
\end{abstract}

Keywords: Legal Awareness, Legal Certainty, Certificate of Land Rights.

\section{PENDAHULUAN}

Tanah merupakan sumber daya alam yang sangat diperlukan sekali oleh manusia yang dikaruniakan langsung oleh Tuhan Yang Maha Esa dimana tanah diperlukan untuk kebutuhan, baik yang langsung seperti bercocok tanam guna mencukupi kebutuhannya, maupun untuk melaksanakan usahanya seperti untuk perdagangan, industri, pembangunan sarana dan prasarana. Menurut Muchtar Wahid dalam penelitiannya tentang Produktivitas Lahan Pertanian Rakyat, tanah merupakan sumber kebutuhan yang hakiki dan berfungsi sangat esensial bagi kehidupan dan penghidupan manusia, bahkan menentukan peradaban sesuatu bangsa. Hal 
serupa ditekankan pula oleh Urip Santoso, menurutnya tanah adalah baik aset fisik maupun hak yang dimiliki pemilik atau orang lain dapat menikmati terhadap hak-hak terdapat di bawah ataupun di atas tanah tersebut. Pengertian tanah dalam konsep ini, meliputi konsep tanah dari aspek fisik dan aspek pemanfaatannya.

Undang-Undang Nomor 5 Tahun 1960 tentang Peraturan Dasar Pokok Agraria (untuk selanjutnya disebut UUPA) tidak memberikan secara jelas mengenai pengertian tentang agraria, hanya saja UUPA memberikan ruang lingkup agraria saja. Dalam ruang lingkup agraria, tanah merupakan bagian dari bumi, yang disebut permukaan bumi. Tanah yang dimaksudkan disini bukan mengatur tanah dalam aspeknya, yaitu tanah dalam pengertian yuridis yang disebut hak. Pengertian agraria memiliki ruang lingkup, yaitu dalam arti sempit, bisa berwujud hak-hak tanah, ataupun pertanian saja, sedangkan Pasal 1 dan Pasal 2 UUPA telah mengambil sikap dalam pengertian yang meluas, yaitu bumi, air, ruang angkasa, dan kekayaan alam yang terkandung di dalam.

Hak-hak atas tanah diatur dalam Pasal 4 ayat (1) UUPA yaitu, "Atas dasar hak menguasai dari negara atas tanah sebagai yang dimaksud dalam Pasal 2 ditentukan adanya macam-macam hak atas permukaan bumi, yang disebut tanah, yang dapat diberikan kepada dan dipunyai oleh orang-orang, baik sendiri maupun bersama-sama dengan orang-orang lain serta badan-badan hukum publik". Adapun hak-hak atas tanah yang dapat dimiliki diatur dalam Pasal 16 UUPA yaitu, hak-hak atas tanah sebagai dimaksud dalam Pasal 4 ayat (1) adalah: Hak Milik, Hak Guna Usaha, Hak Guna Bangunan, Hak Pakai, Hak Sewa, Hak Membuka Tanah, Hak Memungut Hasil Hutan, dan hak-hak lain yang tidak termasuk dalam hak-hak tersebut di atas yang akan ditetapkan dengan undang-undang serta hak-hak yang sifatnya sementara sebagai yang disebutkan dalam Pasal 53 UUPA.

Berdasarkan ketentuan Pasal 16 dapat di lihat dari segi sifatnya hak atas tanah ada yang bersifat sementara dan tetap. Bersifat sementara dapat diartikan pada suatu waktu hak-hak tersebut sebagai lembaga hukum tidak akan ada lagi. Hak-hak yang dimaksud adalah Hak Gadai, Hak Usaha Bagi Hasil, Menumpang dan Hak Sewa untuk usaha pertanian. Sedangkan bersifat tetap disini diartikan sebagai hak yang keberadaanya akan tetap atau terus diakui. Salah satu contoh bersifat tetap adalah Hak Milik. Hak Milik diatur di dalam UUPA secara khusus diatur di dalam Pasal 20 sampai dengan Pasal 27 UUPA. Hak milik menurut Pasal 20 ayat (1) UUPA yaitu: hak yang turun temurun, terkuat dan terpenuh yang dapat dipunyai oleh orang atas tanah, dengan mengingat ketentuan dalam Pasal 6 (fungsi sosial tanah). Kata terkuat dan terpenuh tidak berarti bahwa hak milik itu merupakan hak yang mutlak, tidak dapat diganggu gugat dan tidak terbatas seperti hak eigendom, akan tetapi kata terkuat maksudnya tidak mudah hapus dan musnah serta mudah dipertahankan dan terpenuh, ini menandakan kewenangan pemegang hak milik itu paling penuh dengan dibatasi ketentuan Pasal 6 UUPA tentang fungsi sosial tanah, sedangkan turun termurun, berarti jangka waktu tidak terbatas, dapat beralih karena perbuatan hukum dan peristiwa hukum tertentu semisal perbuatan hukum jual beli, hibah dan atau sebagainya. Menurut Suardi, adapun ciri-ciri dari Hak Milik adalah sebagai berikut:

1. Hak milik merupakan hak atas tanah yang paling kuat artinya tidak mudah hapus serta mudah dipertahankan terhadap gangguan dari pihak lain oleh karena itu maka Hak Milik termasuk salah satu hak yang wajib didaftarkan.

2. Hak milik mempunyai jangka waktu yang tidak terbatas. 
3. Terjadinya hak milik karena hukum adat diatur dengan Peraturan Pemerintah, selain itu juga bisa terjadi karena penetapan pemerintahan atau ketentuan undang-undang.

4. Hak milik dapat dialihkan kepada pihak lain melalui jual-beli, hibah, tukar-menukar, pemberian dengan wasiat, pemberian menurut hukum adat dan lain-lain pemindahan hak yang bermaksud memindahkan hak milik yang pelaksanaannya diatur oleh peraturan perundang-undangan.

5. Penggunaan hak milik oleh bukan pemiliknya dibatasi dan diatur dengan peraturan perundang-undangan.

6. Hak milik dapat dijadikan jaminan hutang dengan dibebani hak tanggungan.

Berdasarkan poin 1 (satu) yang telah tertera di atas, bahwa Hak Milik wajib untuk didaftarkan demi terwujudnya kepastian hukum (rechts zekerheid) terhadap pemegang Hak Milik atas tanah sesuai Pasal 19 ayat (1) UUPA. Pendaftaran tanah sendiri diatur di dalam Peraturan Pemerintah Nomor 24 Tahun 1997 tentang Pendaftaran Tanah. Setelah dilakukan Pendaftaran Tanah yang dimana pendaftaran ini meliputi data fisik dan data yuridis, timbulah sertifikat yang dalam hal ini adalah Sertifikat Hak Milik. Sertifikat merupakan suatu surat tanda yang menyatakan bukti hak, oleh karena itu telah kelihatan berfungsinya, bahwa sertifikat itu berguna sebagai alat bukti. Alat bukti yang menyatakan tanah ini telah diadministrasikan oleh negara melalui Kantor Pertanahan Kotamadya dan Kabupaten setempat.

Kepastian hukum (rechtszekerheid) juga terlihat dalam Pasal 32 ayat (2) Peraturan Pemerintah Nomor 24 Tahun 1997 tentang Pendaftaran Tanah yang menentukan bahwa dalam hal atas suatu bidang tanah sudah diterbitkan sertifikat secara sah atas nama orang atau badan hukum yang memperoleh tanah tersebut dengan itikad baik dan secara nyata menguasainya, maka pihak lain yang merasa mempunyai hak atas tanah itu tidak dapat lagi menuntut pelaksanaan hak tersebut apabila dalam waktu 5 (lima) tahun sejak diterbitikan sertifikat itu tidak mengajukan keberatan secara tertulis kepada pemegang sertifikat dan Kepala Kantor Pertanahan yang bersangkutan ataupun tidak mengajukan gugatan ke Pengadilan mengenai penguasaan tanah atau penerbitan sertifikat tersebut.

Sebagai contoh terdapat salah satu sengketa pertanahan di Bandar Lampung terkait dengan kepemilikan Sertifikat Hak Atas tanah yang terletak di Daerah Korpri berdasarkan Putusan Pengadilan Tata Usaha Negara Nomor : 4/G/2019/PTUN-BL, dalam deskripsinya penggugat memohon kepada Pengadilan Tata Usaha Negara untuk membatalkan 25 Sertifikat Hak Milik Budiyanto, dkk yang diterbitkan oleh Kantor Pertanahan Bandar Lampung. Namun dalam putusannya Hakim menolak semua gugatan yang dimohonkan oleh para penggugat dengan pertimbangan hukum bahwa Sertifikat tersebut telah diterbitkan sesuai dengan peraturan perundang-undangan yang berlaku, sehingga Hakim menyatakan sah kepemilikan Sertifikat Hak Milik atas nama Budiyanto, dkk.

Selain itu topografi Desa Sabah Balau yang memiliki Luas 1.600 Ha, terdiri dari 476,5 Ha peruntukan sawah dan ladang, pemukiman perumahan $330 \mathrm{Ha}$, bangunan umum 0, $25 \mathrm{Ha}$, lainlain 0, 25 Ha. Desa ini juga terdapat 793 Ha areal perkebunan milik PTPN VII. PT Perkebunan Nusantara VII (Persero) adalah salah satu Badan Usaha Milik Negara (BUMN) sektor perkebunan Indonesia. Keberadaan PTPN VII yang secara otomatis akan mendongkrak kualitas dan kesejahteraan SDM Desa Sabah Balau dengan terbukanya lapangan kerja bagi para petani untuk menggarap tanah yang secara regulasi dikuasai oleh PTPN VII terdapat pula potensi masalah yang akan timbul dimasa yang akan datang seperti tumpang tindah kepentingan dan 
pengakuan terhadap kepemilikan hak atas tanah, biasanya problem ini timbul ketika pamanfaatan lahan yang dikuasai oleh PTPN VII telah kadaluarsa, maka tanah tersebut akan dilepaskan kepada Negara serta Masyarakat Desa Sabah Balau punya hak perogratif untuk menguasai tanah bekas garapan tersebut baik seacara fisik maupun yuridis.

Berdasarkan realita kasus yang terjadi tersebut diatas, akan menjadi penting untuk meningkatkan kesadaran hukum masyarakat Desa Sabah Balau mengenai arti pentingnya bukti kepemilikan hak atas tanah yang dalam hal ini adalah Sertifikat. Karena kesadaran hukum merupakan konsepsi abstrak di dalam diri manusia tentang keserasian antara ketertiban dan ketentraman yang dikehendaki oleh masyarakat. Jadi kesadaran hukum akan arti pentingnya sertifikat hak atas tanah dalam hal ini berarti kesadaran untuk mewujudkan kepastian hukum terhadap masyarakat Desa Sabah Balau selaku pemegang hak atas tanah yang diatasnya banyak terkandung nilai-nilai ekonomi dan kesejahteraan bagi pemegang hak.

Berdasarkan latar belakang masalah yang telah diuraikan diatas, maka identifikasi masalah yang ada dalam sasaran Pengabdian kepada Masyarakat ini adalah sebagai berikut:

a. Banyaknya masyarakat Desa Sabah Balau yang masih belum memiliki Sertifikat Hak Atas Tanah terhadap tanah yang dikuasai baik karena peruntukan tempat tinggal atau bahkan pertanian dan perkebunan.

b. Kurangnya kesadaran hukum masyarakat mengenai arti pentingnya sertifikat hak atas tanah sebagai bukti kepemilikan hak atas tanah terkuat.

c. Kurangnya kesadaran hukum masyarakat mengenai konflik hukum pertanahan yang marak di Indonesia saat ini.

d. Belum terwujudnya kesadaran hukum masyarakat mengenai syarat dan mekanisme sertifikasi tanah.

e. Belum optimalnya sosisalisasai dan pendampingan hukum oleh stakeholder terkait seperti Notaris, PPAT, Kepala Desa, Paralegal, Dosen Ilmu Hukum dan Lembaga Bantuan Hukum untuk membantu dan mengurus proses sertifikasi hak atas tanah masyarakat Desa Sabah Balau.

Berangkat dari latar belakang masalah tersebut maka rumusan masalah dalam pengabdian ini adalah terkait dengan optimalisasi kesadaran hukum masyarakat Desa Sabah Balau terhadap kepastian hukum sertifikat hak atas tanah serta kendala optimalisasi kesadaran hukum masyarakat Desa Sabah Balau terhadap kepastian hukum sertifikat hak atas tanah.

\section{METODE}

Metode pelaksanaan dalam kegiatan Pengabdian kepada Masyarakat ini meliputi tahapan persiapan dan tahap pelaksanaan. Adapun ketiga tahapan tersebut akan dijelaskan sebagai berikut:

\section{Tahap Persiapan}

1. Mekanisme pelaksanaan kegiatan pengabdian pada masyarakat meliputi tahapan berikut:

a. Perekrutan anggota pelaksana Pengabdian kepada Masyarakat.

b. Kordinasi dengan tim pelaksana Pengabdian kepada Masyarakat.

c. Kordinasi dan konsultasi dengan Kantor Pertanahan Kabupaten Lampung Selatan.

d. Pembekalan dengan tim pelaksana Pengabdian kepada Masyarakat.

e. Penyiapan sarana dan prasarana terkait dengan pelaksanaan Pengabdian kepada Masyarakat. 
2. Materi persiapan dan pembekalan kepada mahasiswa mencakup:
a. Panduan pelaksanaan kegiatan Pengabdian kepada Masyarakat.
b. Perancangan model kegiatan melalui sosialisasi dan penyuluhan hukum.
c. Penyampaian materi tentang Undang-Undang Nomor 5 Tahun 1960 tentang Peraturan Dasar Pokok Agraria dan Peraturan Pemerintah Nomor 24 Tahun 1997 tentang Pendaftaran Tanah dan peraturan perundang-undangan terkait;

3. Pelaksanaan tahapan kegiatan Pengabdian kepada Masyarakat berlangsung dari Bulan Agustus sampai dengan Bulan Novemer Tahun 2020.

a. Persiapan pelaksanaan Pengabdian kepada Masyarakat di lokasi Pengabdian;
b. Kordinasi dengan pihak Desa Sabah Balau dan Kantor Pertanahan Kabupaten Lampung Selatan.

\section{Tahap Pelaksanaan}

Pelaksanaan program yang akan dilaksanakan dalam Pengabdian kepada Masyarakat ini adalah program penyuluhan hukum terkait dengan optimalisasi kesadaran hukum masyarakat terhadap kepastian hukum Sertifikat Hak Atas Tanah. Selain itu, agar program dari kegiatan tersebut berdampak positif di masyarakat, maka setelah program penyuluhan ini dilakukan akan dilakukan pendampingan oleh pelaksana kegiatan Pengabdian kepada Masyarakat ini.

Metode yang digunakan dalam melakukan pemberdayaan kelompok sasaran adalah pemberian materi dengan cara diskusi dan simulasi. Langkah-langkah operasional yang diperlukan untuk mengatasi permasalahan adalah dilakukan pendampingan secara preventif untuk meningkatkan pemahaman masyarakat terkait dengan aspek-aspek hukum dalam bukti kepemilikan hak atas tanah, sehingga diharapkan dapat meningkatkan kesadaran hukum masyarakat tentang pentingnya sertifikasi hak atas tanah.

\section{Gambaran Umum Lokasi Pengabdian}

\section{HASIL DAN PEMBAHASAN}

Desa Sabah Balau terletak di Kecamatan Tanjung Bintang Kabupaten Lampung Selatan. Wilayah Kabupaten Lampung Selatan terletak antara 1050 14'sampai dengan 1050 45' Bujur Timur dan 50 15' sampai dengan 60 Lintang Selatan. Letak yang demikian ini, maka daerah Kabupaten Lampung Selatan seperti halnya daerah-daerah lain di Indonesia menunjukkan sebagai daerah tropis. Desa Sabah Balau memiliki luas administrasi lahan sebesar 1600 Ha. Wilayah administrasi Desa Sabah Balau berbatasan dengan:

1. Sebelah Utara berbatasan dengan Desa Way Hui

2. Sebelah Selatan berbatasan dengan Desa Lematang

3. Sebelah Barat berbatasan dengan Kelurahan Sukarame

4. Sebelah Timur berbatasan dengan Desa Way Galih

Kejelasan batas-batas tersebut dapat dilihat pada Peta Desa Sabah Balau Kecamatan Tanjung Bintang brikut ini: 


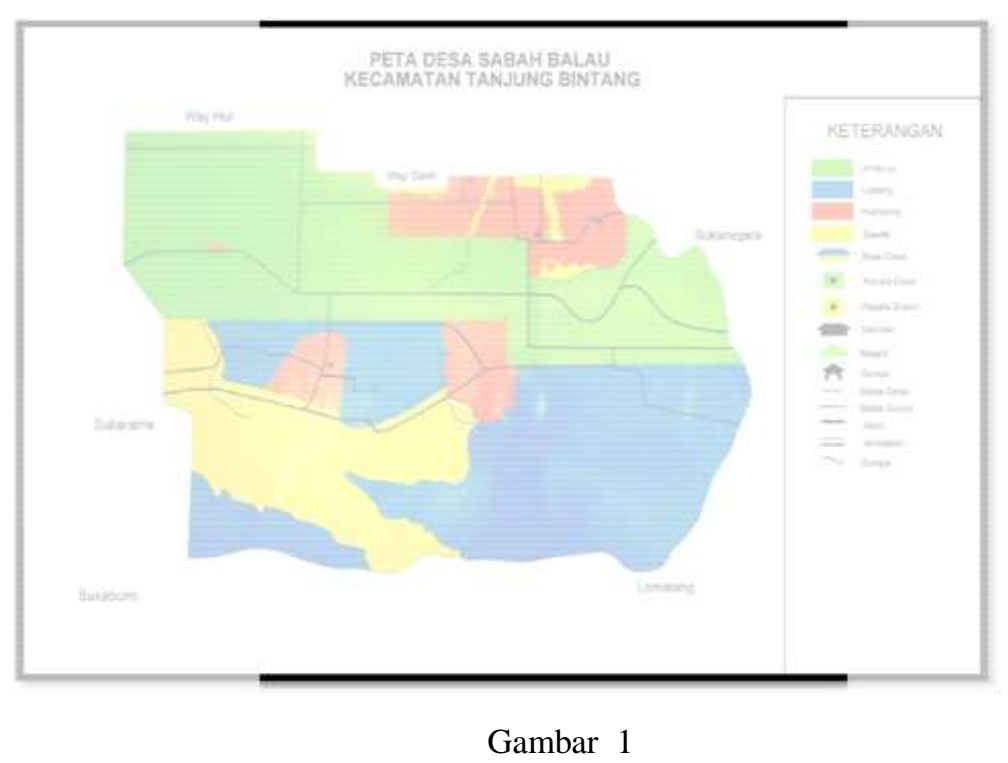

Peta Desa Sabah Balau Kecamatan Tanjung Bintang

Kabupaten Lampung Selatan

Secara administrasi, Desa Sabah Balau merupakan bagian dari Kecamatan Tanjung Bintang. Jarak dari pusat pemerintahan kecamatan $17 \mathrm{Km}$, jarak dari Ibukota kabupaten 75 $\mathrm{Km}$ dan jarak dari Ibukota provinsi $12 \mathrm{Km}$. Letak desa yang berada di perbatasan Kabupaten Lampung Selatan dengan Kota Bandar Lampung menjadikan Desa Sabah Balau lebih dekat dengan pusat pemerintahan Provinsi Lampung. Penduduk Desa Sabah Balau mayoritas terdiri dari berbagai etnis yaitu Jawa, Ogan, dan Banten yang mayoritas Buruh Tani dan Pedagang ternak.

Desa Sabah Balau memiliki Luas $1600 \mathrm{Ha}$, terdiri dari 476,5 Ha peruntukan sawah dan ladang, pemukiman perumahan $330 \mathrm{Ha}$, bangunan umum 0,25 Ha, lain-lain 0,25 Ha. Areal persawahan sebesar 20 Ha seluruhnya merupakan sawah tadah hujan. Di desa ini juga terdapat 793 Ha areal perkebunan milik PTPN VII. PT Perkebunan Nusantara VII (Persero) adalah salah satu Badan Usaha Milik Negara (BUMN) sektor perkebunan Indonesia. Berkantor pusat di Bandar Lampung, Provinsi Lampung yang dibentuk berdasarkan Peraturan Pemerintah Nomor 12 Tahun 1996. PTPN VII (Persero) merupakan penggabungan dari PT Perkebunan X (Persero), PT Perkebunan XXXI (Persero), Proyek Pengembangan PT Perkebunan XI (Persero) di Kabupaten Lahat dan Proyek Pengembangan PT Perkebunan XXIII (Persero) di Provinsi Bengkulu. Perkebunan milik PTPN VII wilayah perseroannya meliputi meliputi 3 (tiga) Provinsi yang terdiri dari 10 Unit Usaha di Provinsi Lampung, 14 Unit Usaha di Provinsi Sumatera Selatan, dan 3 Unit Usaha di Provinsi Bengkulu.

PTPN VII yang berlokasi di Kecamatan Tanjung Bintang Desa Sabah Balau merupakan perusahaan yang menjalankan usaha di bidang agribisnis dan agroindustri, dengan komoditi utama karet. Perseroan didirikan guna melaksanakan dan menunjang kebijaksanaan dan program pemerintah di bidang ekonomi dan pembangunan nasional pada umumnya serta sub-sektor perkebunan pada khususnya. Ini semua bertujuan untuk menjalankan usaha di bidang agribisnis dan agroindustri, serta optimalisasi pemanfaatan sumberdaya Perseroan untuk menghasilkan barang dan/atau jasa yang bermutu tinggi dan berdaya saing kuat untuk 
Seminar Nasional Penelitian dan Pengabdian kepada Masyarakat

Universitas Sang Bumi Ruwa Jurai Tahun 2020

mendapatkan/mengejar keuntungan dalam rangka meningkatkan nilai Perseroan melalui prinsip-prinsip Perseroan Terbatas.

\section{Pembahasan}

\section{Optimalisasi Kesadaran Hukum Masyarakat Desa Sabah Balau Terhadap Kepastian Hukum Sertifikat Hak Atas Tanah}

Kesadaran hukum merupakan nilai-nilai yang terkandung dalam diri manusia secara individual. Kesadaran hukum masyarakat dapat diukur dengan menggunakan indikatorindikator kesadaran hukum yang masing-masing merupakan suatu tahapan bagi tahapan berikutnya yaitu pengetahuan hukum, pemahaman hukum, sikap hukum dan pola perilaku hukum.

Indikator-indikator kesadaran hukum masyarakat mulai dari yang terendah sampai dengan yang tertinggi. Sehingga dalam penelitian ini, pengetahuan hukum, pemahaman hukum, sikap hukum, dan pola perilaku hukum dijadikan patokan untuk mengetahui apakah masyarakat Desa Sabah Balau Kecamatan Tanjung Bintang Kabupaten Lampung Selatan talah memenuhi atau tidak memenuhi empat indikator kesadaran hukum dalam memperoleh sertifikat hak atas tanah, penulis menggunakan pendekatan teori kesadaran hukum yang dikemukakan oleh Soerjono Soekanto.

Beberapa pendapat responden di atas mewakili keseluruhan responden yang pernah melakukan pengurusan sertifikat hak atas tanah dan tidak pernah melakukan pengurusan sertifikat hak atas tanah. Responden belum memiliki sertifikat hak atas tanah tidak pernah melakukan pengurusan sertifikat hak atas tanah karena dipengaruhi oleh faktor pengetahuan dan pemahaman hukum, biaya administrasi, serta belum adanya sosialisasi dari pemerintah yang terkait tentang pengurusan sertifikat hak atas tanah dan faktor-faktor lain yang menyangkut urusan pribadi. Keseluruhan olahan data wawancara dari pengetahuan hukum, pemahaman hukum, sikap hukum dan pola perilaku hukum masyarakat dalam penelitian ini, maka dapat dikatakan indikator kesadaran hukum masyarakat dalam memperoleh sertifikat hak atas tanah di Desa Sabah Balau Kecamatan Tanjung Bintang Kabupaten Lampung Selatan dikatakan belum memenuhi empat indikator kesadaran hukum atau masih rendah. Hal ini dapat dilihatkurangnyabeberapa aspek indikator pengetahuan hukum masyarakat, indikator pemahaman hukum masyarakat, indikator sikap hukum masyarakat dan, indikator pola perilaku hukum masyarakat khususnya masyarakat yang belum memiliki sertifikat. Masyarakat Desa Sabah Balau yang tidak memiliki sertifikat hak atas tanah perlu mendapatkan perhatian lebih dari pihak pemerintah Kelurahan maupun pihakpemerintah yang menangani persoalan ini yang berkaitan dengan masalah agraria. Karena sebagian masyarakat Desa Sabah Balau terkhusus kepada masyarakat yang belum memiliki sertifikat benar-benar tidak mengetahui proses-proses yang berkaitan dengan tata cara dan tujuan dalam memperoleh sertifikat hak atas tanah. Sedangkan masyarakat Desa Sabah Balau khususnya yang sudah memiliki sertifikat telah mengetahui dampak negatif dari ketiadaannya memiliki sertifikat hak atas tanah.

Kesadaran hukum masyarakat dalam memperoleh sertifikat hak atas tanah adalah langkah awal dalam mewujudkan tertib administrasi di Instansi pertanahan sehingga meminimalisir terjadinya sengketa dalam bidang pertanahan. Kesadaran hukum masyarakat tentunya berbeda antara individu yang satu dengan individu yang lainnya ada yang memiliki pengetahuan dan pemahaman hukum dan ada pula yang tidak memiliki pengetahuan dan pemahaman tentang suatu peraturan yang berkaitan dengan pembuatan sertifikat tanah hal tersebut tentunya di pengruhi oleh faktor-faktor tertentu.

Berdasarkan hasil wawancara dengan masyarakat yang memiliki tanah yang sudah memiliki sertifikat dan belum memiliki sertifikat serta dengan pihak pemerintah yaitu Kepala Desa diperoleh gambaran bahwa, faktor-faktor yang mempengaruhi kesadaran hukum masyarakat dalam memperoleh sertifikat hak atas tanah di Desa Sabah Balau Kecamatan 
Tanjung Bintang Kabupaten Lampung Selatan dalam melakukan pengurusan sertifikat hak atas tanah adalah sebagai berikut:

1. Faktor pengetahuan hukum masyarakat Desa Sabah Balau

Mengenai bukti-bukti kepemilikan hak atas tanah bukti yang dimaksud dalam masalah penelitian ini adalah sebagai dasar untuk menentukan bahwa seseorang memiliki sebidang tanah yang didukung oleh pengakuan saksi serta pemerintah Desa setempat dan keterangan lain semisal memiliki bukti surat jual beli dari pemilik tanah sebelumnya.

2. Faktor Pemahaman Hukum Masyarakat dalam Pengurusan Sertifikat Hak atas Tanah

Masyarakat Desa Sabah Balau Kecamatan Tanjung Bintang terkhusus masyarakat yang belum memiliki sertifikat cenderung tidak mau tahu tentang eksistensi arti pentingnya memiliki pemahaman hukum dalam memperoleh sertifikat hak atas tanah, dapat dilihat dari masih adanya masyarakat yang belum memiliki sertifikat tanah dan bidang-bidang tanah yang belum bersertifikat dengan berbagai alasan belum ada niatan untuk mensertifikasi hak atas tanahnya memiliknya.

3. Faktor Ekonomi

Faktor ekonomi tentunya dapat menjadi faktor pendukung dan faktor mempengaruhi kesadaran masyarakat dalam pengurusan sertifikat hak atas tanah. Dalam proses pengurusan sertifikat masyarakat yang memiliki materi yang cukup tentunya tidak ada kesulitan dalam hal mengurus sertifikatnya berbeda dengan masyarakat dengan tingkat ekonomi lemah tentunya mereka berpikir dua kali untuk mensertifikasi hak atas tanahnya dengan pertimbangan mereka harus memenuhi kebutuhan sehari-hari.

4. Faktor Peningkatan Kesadaran Hukum

Peningkatan kesadaran hukum seyogyanya dilakukan melalui penerangan dan penyuluhan hukum yang teratur atas dasar perencanaan yang mantap kepada masyarakat, tentunya dalam kaitan dengan pengurusan sertifikat hak atas tanah. Peningkatan kesadaran hukum adalah kegiatan rutin yang dilaksanakan oleh pemerintah agar masyarakat yang belum memiliki sertifikat tanah dapat mengetahui dan memahami hukum yang berkaitan tentang pengurusan sertifikat hak atas tanah.

\section{Waktu Pembuatan Sertifikat Hak Atas Tanah}

Waktu pembuatan sertifikat hak atas tanah adalah faktor yang cukup berpengaruh terhadap kesadaran hukum masyarakat dalam memperoleh sertifikat hak atas tanah, waktu pembuatan sertifikat yang lama membuat masyarakat enggan untuk melakukan pengurusan sertifikat hak atas tanah karena menganggap pihak pemerintah lamban dalam pengurusan sertifikat hak atas tanah.

Berangkat dari faktor-faktor yang mempengaruhi kesadaran hukum masyarakat dalam memperoleh sertifikat hak atas tanah di Desa Sabah Balau Kecamatan Tanjung Bintang Kabupaten Lampung Selatan dalam melakukan pengurusan sertifikat hak atas tanah, maka optimalisasi yang harus ditempuh dalam hal meningkatkan kesadaran hukum masyarakat Desa Sabah Balau terhadap kepastian hukum sertifikat hak atas tanah dapat diaplikasikan dengan mendorong kemauan masyarkat Desa Sabah Balau untuk mendaftarkan tanahnya serta menanamkan rasa takut akan terjadinya klaim sepihak dari pihak lain yang tidak bertanggungjawab.

Hal ini dapat diketahui dari kutipan wawancara berikut : 
Seminar Nasional Penelitian dan Pengabdian kepada Masyarakat Universitas Sang Bumi Ruwa Jurai Tahun 2020

"saya awalnya memang sudah berkeinginan untuk mendaftarkan tanah milik ibu saya ini supaya untuk menghindari hal-hal yang tidak diinginkan, karena kan tempat kita berdeketan dengan perkotaan, dan takutnya ada masalah sengketa disini".

Selain itu diperkuat juga hal ini oleh narasumber lainnya yang mengungkapkan sebagai berikut: "saya dari tahun-tahun sebelumnya sudah punya niatan untuk mendaftarkan tanah saya, tapi saya mengurungkan niat saya karena saya karena takut kedepannya terjadi hal-hal yang tidak saya inginkan."

Berdasarkan hasil wawancara diatas, diketahui bahwa masyarakat Desa Sabah Balau memiliki keinginan besar untuk bisa mendaftarkan tanahnya supaya tidak tersangkut kasus sengketa tanah, secara tidak langsung tempat tinggalnya saat ini berdekatan dengan perkotaan sehingga rumah yang ditempatinya saat ini takut terkena hal-hal yang tidak diinginkan. Dengan timbulnya rasa takut yang dialami narasumber ini, maka masyarakat berupaya untuk mendaftarkan tanahnya.

Namun hanya saja, permasalahan dan faktor penghambat yang terjadi adalah sulitnya masyarakat untuk merealisasikan keinginannya untuk mendaftarkan tanahnya, oleh karena itu perlu perhatian lebih dari pemerintah ataupun akademisi untuk sosialisasi hukum tentang tata cara pendaftaran tanah yang benar agar setiap masyarakat dapat merealisasikan keinginannya untuk mendaftarkan tanahnya tersebut.

\section{Kendala Optimalisasi Kesadaran Hukum Masyarakat Desa Sabah Balau Terhadap Kepastian Hukum Sertifikat Hak Atas Tanah}

Kendala optimalisasi kesadaran hukum masyarakat Desa Sabah Balau terhadap kepastian hukum sertifikat hak atas tanah disebabkan oleh beberapa faktor, yaitu belum adanya bentuk tindakan (action) dan pendidikan (education) dari stakeholder terkait.

\section{a. Tindakan (action)}

Tidak adanya tindakan penyadaran hukum pada masyarakat Desa Sabah Balau, yaitu dengan memberikan pendampingan kepada masyarakat Desa untuk pengurusan sertifkasi hak atas tanh.

b. Pendidikan (education)

Kurangnya pendidikan yang dilakukan baik secara formal maupun nonformal. Pendidikan kepada masyarakat Desa Sabah Balau perlu diperhatikan dan ditanamkan dalam pendidikan formal / non formal adalah pada pokoknya tentang bagaimana menjadi warganegara yang baik, tentang apa hak serta kewajiban seorang warga negara.

Menanamkan kesadaran hukum berarti menanamkan nilai-nilai kebudayaan. Dan nilainilai kebudayaan dapat dicapai dengan pendidikan. Oleh karena itu setelah mengetahui kemungkinan sebab-sebab merosotnya kesadaran hukum masyarakat usaha pembinaan yang efektif dan efesien ialah dengan pendidikan.

c. Pendidikan Non Formal.

Belum eksisnya pendidikan non formal yang ditujukan khusus kepada masyarakat Desa Sabah Balau. Pedidikan non formal dapat dilakukan dengan beberapa cara, antara lain : penyuluhan hukum, kampanye, dan pameran

\section{KESIMPULAN}

1. Optimalisasi kesadaran hukum masyarakat Desa Sabah Balau terhadap kepastian hukum sertifikat hak atas tanah adalah dapat diaplikasikan dengan mendorong kemauan masyarkat Desa Sabah Balau 
untuk mendaftarkan tanahnya serta menanamkan rasa takut akan terjadinya klaim sepihak dari pihak lain yang tidak bertanggungjawab yang berpotensi sengketa dikemudian hari.

2. Kendala optimalisasi kesadaran hukum masyarakat Desa Sabah Balau terhadap kepastian hukum sertifikat hak atas tanah adalah belum adanya bentuk tindakan (action) seperti pendampingan khusus terhadap sertifkasi tanah masyarakat Desa Sabah balau serta belum eksisnya pendidikan (education) dari stakeholder terkait seperti perangkat Desa dan Pemerintah dan Akademisi baik secara formal dan non formal.

\section{DAFTAR PUSTAKA}

Ali Achmad dan wiwie Heryani, 2012, Menjelajahi Kajian Empiris Terhadap Hukum, Jakarta, Kencana.

Arba H.M, 2016, Hukum Agraria Indonesia, Jakarta, Sinar Grafika.

Harsono Boedi, 2005, Hukum Agraria Indonesia Sejarah Pembentukan Undang-Undang Pokok Agraria , Isi dan Pelaksanaannya, Jakarta, Djambatan.

Marzuki Peter Mahmud, 2008, Pengantar Ilmu Hukum, Jakarta, Kencana.

Mas Marwan, 2014, Penghantar Ilmu Hukum, Bogor, Penerbit Ghaila Indonesia.

Maulidiana Lina, Rendy Renaldy, Jaminan Hak Atas Tanah Sertifikat Yang Diperoleh Dari Pewarisan Dalam Pembebanan Hak Tanggungan, Justicia Sains: Jurnal Ilmu Hukum, doi: http://dx.doi.org/10.24967/jcs.v4i1.414, Vol. 04 No. 02 November 2019

Mertokusumo Sudikno, 1981, Menigkatkan Kesadaran Hukum Masyarakat, Edisi Pertama, Yogyakarta, Liberti.

Peraturan Pemerintah Nomor 24 tahun 1997 tentang Pendaftara Tanah

Rato Dosminikus, 2010, Filasafat Hukum Mencari dan Memahami Hukum, Yogyakarta, PT Presindo.

Salman Otje, 1993, Kesadaran Hukum Masyarakat Terhadap Hukum Waris, Bandung, Alumni.

Santoso Urip, 2012, Hukum Agraria Kajian Komprehensif, Jakarta, Kencana.

Soekanto Soerjono, 1982, Kesadaran Dan Kepatuhan Hukum, Jakarta, Rajawali Pers.

Soekanto Soerjono, 2002, Kesadaran Hukum dan Kepatuhan Hukum, Jakarta, Raja Grafindo Persada.

Syahrani Riduan, 1999, Rangkuman Intisari Ilmu Hukum, Bandung, Citra Aditya.

Wahid Muchtar, 2008, Memaknai Kepastian Hukum Hak Milik Atas Tanah, Republika, Jakarta.

Undang-Undang Nomor 5 tahun 1960 tentang Peraturan Dasar Pokok Agraria 